\title{
The Rad50 hook domain regulates DNA damage signaling and tumorigenesis
}

\author{
Ramon Roset, ${ }_{1}^{1}$ Akiko Inagaki, ${ }^{1}$ Marcel Hohl, ${ }^{1}$ Fabienne Brenet, ${ }^{2}$ Julien Lafrance-Vanasse, ${ }^{3}$ \\ Julian Lange, ${ }^{1}$ Joseph M. Scandura, ${ }^{2}$ John A. Tainer, ${ }^{3}$ Scott Keeney, ${ }^{1,4,5}$ and John H.J. Petrini ${ }^{1,5,6}$ \\ ${ }^{1}$ Molecular Biology Program, Memorial Sloan-Kettering Cancer Center, New York, New York 10021, USA; ${ }^{2}$ Department \\ of Medicine, Laboratory of Molecular Hematopoiesis, Weill-Cornell Medical College, New York, New York 10065, USA; \\ ${ }^{3}$ Life Sciences Division, Lawrence Berkeley National Laboratory, Berkeley, California 94720, USA; ${ }^{4}$ Howard Hughes Medical \\ Institute, Memorial Sloan-Kettering Cancer Center, New York, New York 10065, USA; ${ }^{5}$ Weill Graduate School of Medical \\ Sciences, Cornell University, New York, New York 10021, USA
}

The Mre11 complex (Mre11, Rad50, and Nbs1) is a central component of the DNA damage response (DDR), governing both double-strand break repair and DDR signaling. Rad50 contains a highly conserved $\mathrm{Zn}^{2+}$-dependent homodimerization interface, the Rad50 hook domain. Mutations that inactivate the hook domain produce a null phenotype. In this study, we analyzed mutants with reduced hook domain function in an effort to stratify hookdependent Mre11 complex functions. One of these alleles, $\operatorname{Rad}^{4}{ }^{46}$, conferred reduced $\mathrm{Zn}^{2+}$ affinity and dimerization efficiency. Homozygous Rad50 $0^{46 / 46}$ mutations were lethal in mice. However, in the presence of wildtype $\operatorname{Rad} 50, \operatorname{Rad}^{46}{ }^{46}$ exerted a dominant gain-of-function phenotype associated with chronic DDR signaling. At the organismal level, $\mathrm{Rad}_{50^{+/ 46}}$ exhibited hydrocephalus, liver tumorigenesis, and defects in primitive hematopoietic and gametogenic cells. These outcomes were dependent on ATM, as all phenotypes were mitigated in $\operatorname{Rad}^{+/ 46} \mathrm{Atm}^{+/-}$mice. These data reveal that the murine Rad50 hook domain strongly influences Mre11 complex-dependent DDR signaling, tissue homeostasis, and tumorigenesis.

[Keywords: Mre11 complex; double-strand breaks; Rad50; ATM]

Supplemental material is available for this article.

Received December 18, 2013; revised version accepted January 16, 2014.

The Mre11 complex is a large multicomponent assembly that comprises two Mre11, two Rad50, and two Nbs1 (Xrs2 in Saccharomyces cerevisiae) molecules that plays a central role in the DNA damage response (DDR). The complex consists of a globular domain in which Mre11 and Nbs1 associate with the Walker A and B domains of Rad50 (Fig. 1A). A large coiled-coil domain of Rad50 extends out from the globular domain and folds back on itself in an anti-parallel manner, with the Rad50 hook domain at the apex. The hook domain is a highly conserved interface that mediates homotypic dimerization via the coordination of a $\mathrm{Zn}^{2+}$ atom by two invariant cysteines from each of two Rad50 protomers (Hopfner et al. 2002).

The Mre11 complex is a sensor of DNA double-strand breaks (DSBs) that is required for DDR signaling primarily via the kinase ATM (Stracker and Petrini 2011). Recent data suggest that the complex may also influence the activation of ATR, which is primarily activated in response

${ }^{6}$ Corresponding author

E-mail petrinij@mskcc.org

Article published online ahead of print. Article and publication date are online at http://www.genesdev.org/cgi/doi/10.1101/gad.236745.113. to DNA replication stress (Stiff et al. 2005; Duursma et al. 2013; Shiotani et al. 2013). These observations underlie the view that the Mre11 complex plays an integral role in the regulation of signaling within the DDR network.

The Mre11 complex plays a key role in DSB repair, promoting both homology-directed DSB repair (HDR) and nonhomologous end-joining (NHEJ). With respect its role in HDR, genetic and physical evidence suggests that the primary function of the Mrell complex is to promote HDR between sister chromatids via the hook and coiled-coil domains of Rad50 (Bressan et al. 1999; Hartsuiker et al. 2001; Gonzalez-Barrera et al. 2003; Wiltzius et al. 2005; Hohl et al. 2011). Mre11 complex-mediated NHEJ appears to be primarily dependent on DNA-binding sites in the globular domain (Williams et al. 2008, 2009), although we showed that the hook and coiled-coil domains also influence this process, presumably via long-range effects on the disposition of globular domain components (Hohl et al. 2011).

(C) 2014 Roset et al. This article is distributed exclusively by Cold Spring Harbor Laboratory Press for the first six months after the full-issue publication date (see http://genesdev.cshlp.org/site/misc/terms.xhtml). After six months, it is available under a Creative Commons License (AttributionNonCommercial 3.0 Unported), as described at http://creativecommons.org/ licenses/by-nc/3.0/. 
A

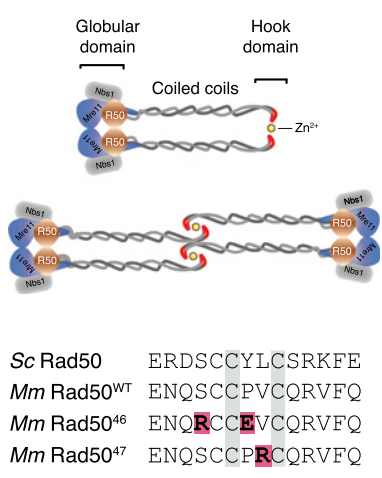

C

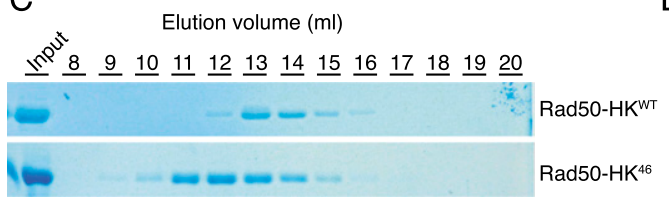

B

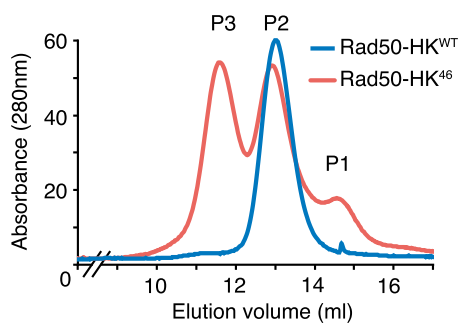

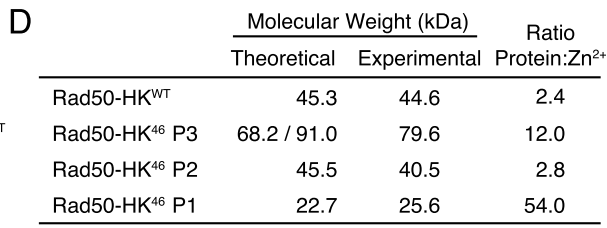

Figure 1. Analysis of Rad50 hook dimerization. (A, top panel) Schematic representation of the Mre11 complex in two possible configurations. Rad50 globular domain shown in brown, Mre11 is in blue, and Nbs1 is in gray. (Bottom panel) Sequence of the hook domain from S. cerevisiae, Mus musculus, and the Rad50 $0^{46}$ and Rad50 $0^{47}$ mutants. $(B)$ Gel filtration profile of Rad50-HK proteins. (C) Fractions from $B$ were resolved on an acrylamide gel and stained with Coomassie. $(D)$ Molecular weight and $\mathrm{Zn}^{2+}$ content of the indicated Rad50-HK proteins determined by SEC-MALS and ICP-MS, respectively. Theoretical molecular weight for a monomeric (P1), dimeric (P2 and Rad50-HK $\left.{ }^{\mathrm{WT}}\right)$, and trimeric/tretrameric (P3) species.

Structural analyses of the complex suggest a model in which the Mre11 complex's effect on DSB repair is attributable to its ability to bridge DNA molecules in trans and in cis (de Jager et al. 2001, 2004; van Noort et al. 2003; Moreno-Herrero et al. 2005). In trans, two complexes bind DNA independently by their globular domains and, via association through the Rad50 hook domain, would bridge sister chromatids and promote HDR between them. Indeed, studies in yeast have shown that the dimerization function of the hook domain underlies the influence of this domain on DSB repair, telomere maintenance, and meiotic DSB formation (Wiltzius et al. 2005). In cis, the globular domain could bridge two DNA ends in a manner that would promote NHEJ (Williams et al. 2008). In this mode, end-to-end DNA bridging is effected by adjacent monomeric components of the dimeric globular domain (Lammens et al. 2011; Lim et al. 2011).

Mutations that target the invariant cysteines of the Rad50 hook domain (Hopfner et al. 2002; Wiltzius et al. 2005; Hohl et al. 2011; He et al. 2012) globally disrupt Mre11 complex functions and thus phenocopy the null Rad50 mutation. Hence, the specific contribution of the Rad50 hook to the repair and signaling functions of the Mre11 complex has not been examined in isolation from the other domains of the complex.

To gain insight into Rad50 hook domain's role, our laboratory targeted the residues adjacent to the invariant cysteine residues in S. cerevisiae in an effort to obtain hypomorphic alleles. The alleles obtained were examined and found to encode hook domains with reduced $\mathrm{Zn}^{2+}$-dependent dimerization and increased DNA damage sensitivity (M Hohl, C Tous, T Kochańczyk, A Krężel,
A Aguilera, and JHJ Petrini, in prep.). In this study, two of the yeast alleles (rad50-46 and rad50-47) were modeled in mice.

We found that in the absence of the wild-type Rad50 protein, both $\operatorname{Rad} 50^{46}$ and $\operatorname{Rad} 50^{47}$ alleles failed to support viability at either the cellular or organismal level, consistent with the view that the Rad50 hook domain is integral to the functions of the Mrel1 complex. The Rad50 $0^{46}$ and Rad $50^{47}$ gene products exerted dominant gains of function in the presence of the wild-type protein.

Heterozygous $\mathrm{Rad}_{50} \mathrm{O}^{+/ 46}$ and $\mathrm{Rad} 5 \mathrm{O}^{+/ 47}$ cells were relatively proficient in DNA repair but exhibited chronic DDR signaling at the cellular level and severe ATMdependent phenotypes at the organismal level. The data suggest that the Rad50 $0^{46}$ and Rad $50^{47}$ proteins promote aberrant heterotypic dimerization at the hook domain interface. As the functional defect imparted by $\operatorname{Rad} 50^{46}$ and $R a d 50^{47}$ predominantly affected Mre11 complexdependent DDR signaling, these data reveal a previously unrecognized influence of the Rad50 hook domain on Mre11 complex-dependent regulation of the apical DDR kinases.

\section{Results}

\section{Rad50 hook domain mutants}

Having previously shown that alteration of the cysteine residues of the Rad50 hook domain was tantamount to complete elimination of the protein (Hopfner et al. 2002), we reasoned that alteration of adjacent residues might result in a partial loss of function that would provide 
insight regarding the functional importance of the Rad50 hook. Using S. cerevisiae, we identified two mutants, designated rad50-46 and rad50-47, that behaved as hook domain hypomorphs and have in common the presence of charged residues in the vicinity of the cysteines that coordinate zinc (Fig. 1A). As a consequence, both mutants showed reduced hook-mediated dimerization and reduced affinity for $\mathrm{Zn}^{2+}$ (M Hohl, C Tous, T Kochańczyk, A Krężel, A Aguilera, and JHJ Petrini, in prep.).

A $22.7-\mathrm{kDa}$ fragment of bacterially produced mouse Rad50 (Rad50-HK) that contained the hook domain flanked by small segments of the coiled-coil region was purified and examined by size exclusion chromatography and multiangle light scattering (SEC-MALS). Rad50-HK ${ }^{\mathrm{WT}}$ eluted as a single peak (Fig. 1B,C) with a molecular weight of 44.6 $\mathrm{kDa}$, indicating a dimeric species. Inductively coupled mass spectrometry (ICP-MS) revealed that the protein to $\mathrm{Zn}^{2+}$ molar ratio of this species was 2.4, approximating the expected value of 2 for a $\mathrm{Zn}^{2+}$-dependent dimer (Fig. 1D). In contrast, Rad50- $\mathrm{HK}^{46}$ eluted in three peaks (Fig. 1B). Peak 2 (P2) was similar to Rad50-HK ${ }^{\mathrm{WT}}$ in molecular weight and $\mathrm{Zn}^{2+}$ content. Peak 1 (P1) and peak 3 (P3) contained very little $\mathrm{Zn}^{2+}$ and represent monomers and higher-molecular-weight aggregates, respectively (Fig. 1D). These data suggest that the Rad50 $0^{46}$ hook domain is structurally compromised but retains some ability to dimerize and bind $\mathrm{Zn}^{2+}$.

\section{Derivation of $\operatorname{Rad} 50^{46}$ and $\operatorname{Rad} 50^{47}$ mice}

To analyze the function of the Rad50 hook in vivo, mice expressing analogs of the yeast rad50-46 and rad50-47 alleles were derived. The mice initially retained a LoxPflanked neo cassette within intron 13 of the mutant Rad50 locus (Supplemental Fig. S1A,B). These alleles were designated Rad50 $0^{+/ N e o 46}$ and Rad50 $0^{+/ N e o 47}$. Rad50 $0^{+/ N e o 47}$ chimeric mice were unable to produce viable offspring. No live $\mathrm{Rad} 5 \mathrm{O}^{+/ \mathrm{Neo} 47}$ births were noted among 327 pups produced from 27 different chimeras. PCR genotyping of tissues from $\mathrm{Rad} 50^{+/ \mathrm{NeO} 47}$ chimeras (including isolated sperm) indicated that the Rad50 ${ }^{N e o 47}$ allele was present (Supplemental Fig. S1C). On this basis, we concluded that the Rad50 Neo47 allele exerted a dominant lethal effect. In contrast, Rad50+/Neo46 chimeric mice transmitted the Rad50 Neo46 allele to viable offspring, and $50 \%$ of the embryonic stem cell-derived pups were $\mathrm{Rad} 50^{+/ \mathrm{Neo} 46}$.

Rad50 Neo46 also exerted a dominant phenotype. The effects observed were more pronounced following deletion of the LoxP-flanked neo cassette (henceforth Rad50 $0^{+/ 46}$ mice) by crossing to CAG-Cre mice. Rad50 $0^{+/ 46}$ mice were born at the expected Mendelian ratios but displayed intense skin hyperpigmentation (Fig. 2A), and $27 \%$ of them developed hydrocephalus compared with $4 \%$ of $\mathrm{Rad}_{50} \mathrm{O}^{+\mathrm{Ne} 046}$ (Fig. 2B). RT-PCR analysis indicated that the expression of $\operatorname{Rad} 50^{\mathrm{Neo} 46}$ was lower than Rad50 $^{46}$ (Supplemental Fig. S1D). Hence, the extent of dominance was correlated with the dosage of the Rad50 ${ }^{46}$ gene product.

Rad50 ${ }^{+/ 46}$ males were infertile (discussed further below). This precluded interbreeding of heterozygotes to obtain Rad50 $46 / 46$ mice. Instead, Rad50 $0^{+/ 46}$ females were

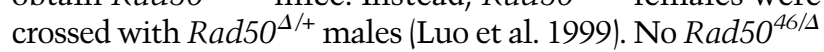
mice were obtained from 90 offspring $\left(\chi^{2}, P<10^{-4}\right)$, indicating that the $R a d 50^{46}$ allele does not support embryonic viability.

$\operatorname{Rad} 50^{+/ 46}$ and $\operatorname{Rad} 50^{+/ \Delta}$ mice were crossed with Rad50 indind (in which exons 1 and 2 are flanked by lox $P$ sites) (Adelman et al. 2009) and a tamoxifen-inducible Cre (Ventura et al. 2007). In this setting, Cre-mediated excision of the floxed exons of the Rad50 ind allele to generate Rad50 ${ }^{46 /-}$ and $\mathrm{Rad} 50^{4 /-}$ cells in vivo was carried out. The induction of Cre is variable in vivo, and so affected tissues were likely to exhibit mosaicism for the deletion genotype. Tamoxifen administered in the food produced excision in the Rad50 ind allele in various tissues but was predominant in the intestine (Supplemental Fig. S2B). Rad50 $0^{46 /-}$ and Rad50 $0^{\Delta /-}$ mosaic mice did not live beyond $2 \mathrm{wk}$ due to intestinal failure. Histological analysis of the gut $9 \mathrm{~d}$ after beginning the treatment evidenced a profound alteration of Rad50 $0^{46 /-}$ intestinal morphology (Supplemental Fig. S2C). These data indicate that the $\operatorname{Rad} 50^{46}$ allele does not support the viability of proliferating cells in vivo.

DNA repair and checkpoint signaling in $\mathrm{Rad} 50^{+/ 46}$ cells

We sought to determine the molecular basis of the $\mathrm{Rad} 50^{+/ 46}$ phenotype. SV40-immortalized Rad50 $0^{+/ 46}$ and Rad50 $0^{+/+}$ mouse embryonic fibroblasts (MEFs) showed similar levels of Mre11 complex proteins, and immunoprecipitations indicated that complex integrity was not overtly compromised (Fig. 2C).

The DNA repair functions of the Mre11 complex were modestly affected in Rad50 $0^{+/ 46}$ cells. Rad50 $0^{+/ 46}$ cells showed increased sensitivity to camptothecin at high doses (Fig. 2D) but were not sensitive to other DNAdamaging agents (Supplemental Fig. S3A). Accordingly, treatment with clastogens failed to increase the yield of chromosomal aberrations relative to wild-type cells (Supplemental Fig. S3B). The DR-GFP assay, in which an I-SceI/GFP reporter is integrated at the Pim1 locus (Kass et al. 2013), was employed to assess HDR proficiency. An I-SceI-IRES-hCD4 retroviral vector, which allowed cell sorting of I-SceI-expressing cells, was used to minimize the confounding effects of poor transfectability and varying transfection efficiencies of the cells examined. We found that $\mathrm{Rad} 5 \mathrm{O}^{+/ 46}$ cells consistently exhibited a trend of lower HDR efficiency, although the difference was not statistically significant $(P=0.17)$ (Fig. 2E).

The Mre11 complex is required for ATM activation (Stracker and Petrini 2011). Rad50 ${ }^{+/ 46}$ cells exhibited indices of spontaneous ATM activation, including pS1987ATM and $\gamma \mathrm{H} 2 \mathrm{AX}$ formation (Fig. 2F). IR-induced ATM activation in $\mathrm{Rad} 50^{+/ 46}$ cells was otherwise normal and occurred with wild-type kinetics (Fig. 2F). Rad50 $0^{+/ 47}$ skin fibroblasts generated from chimeric mice phenocopied Rad50 ${ }^{+/ 46}$ cells in all respects (Supplemental Fig. S4). These results suggested that $\operatorname{Rad} 50^{+/ 46}$ (and Rad50 $0^{+/ 47}$ ) cells exhibited spontaneous DNA damage. An alternative nonexclusive possibility is that the $\operatorname{Rad} 50^{46}$ and $\operatorname{Rad} 50^{47}$ alleles are hypermorphic with respect to DNA damage 
Roset et al.

A

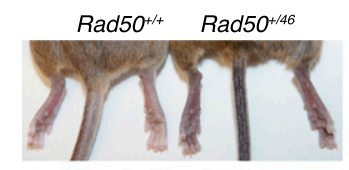

C

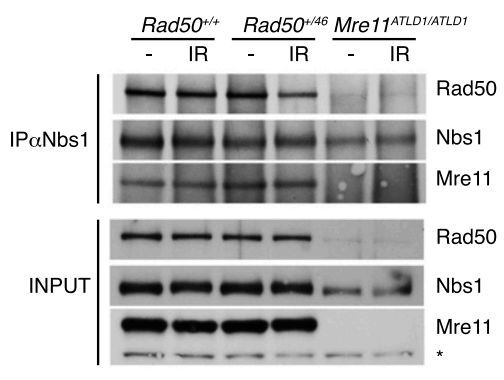

B

\begin{tabular}{|c|c|c|}
\hline & Normal & Hydrocephalus \\
\hline $\operatorname{Rad} 50^{+ \text {+Neo46 }}$ & $134(96 \%)$ & $6(4 \%)$ \\
\hline $\operatorname{Rad} 50^{+/ 46}$ & $88(73 \%)$ & $32(27 \%)$ \\
\hline $\operatorname{Rad} 50^{+466} \mathrm{Atm}^{+/}$ & $23(100 \%)$ & $0(0 \%)$ \\
\hline
\end{tabular}

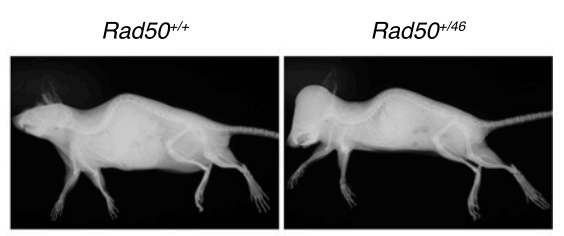

D

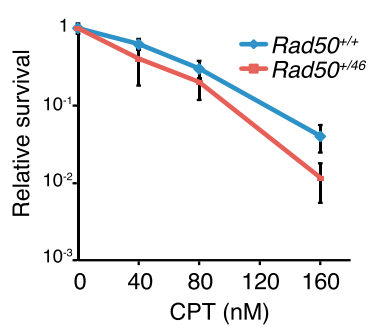

E

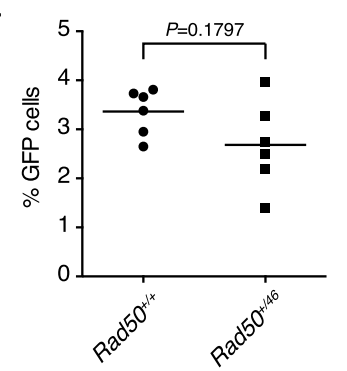

F

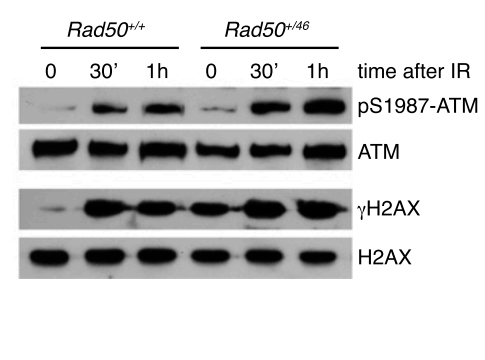

Figure 2. $R a d 50^{46}$ allele is dominant. $(A)$ Representative image showing hyperpigmentation in tail and paws in a $R a d 50^{+/ 46}$ mouse

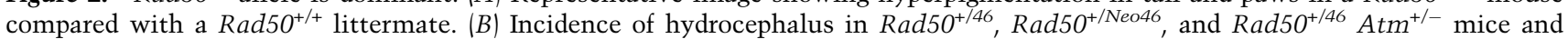
representative X-ray images of an 8 -wk-old Rad50 ${ }^{+/ 46}$ mouse with hydrocephalus and a Rad50 $0^{+/+}$littermate. $(C)$ Rad50, Mre11, and Nbs1 protein levels in $\mathrm{Rad} 5 \mathrm{O}^{+/+}$and $\mathrm{Rad} 5 \mathrm{O}^{+/ 46} \mathrm{SV} 40$-immortalized MEFs and Nbs1 immunoprecipitation to assess Mre11 complex integrity in mock-treated cells (-) or $1 \mathrm{~h}$ after 5 Gy IR. Mre11 ${ }^{\text {ATLD1/ATLD1 }}$ cells were used as control for cells with reduced Mre11 complex levels (Theunissen et al. 2003). (D) SV40-immortalized MEFs were treated with camptothecin for $24 \mathrm{~h}$, and colonies were assessed $10 \mathrm{~d}$ later. Experiments were done three times in triplicate using two independent cell lines per genotype. Error bars depict standard deviation (SD). (E) Primary mouse fibroblasts Rad50 ${ }^{+/+} \operatorname{Pim}^{+/ D R-G F P}$ and Rad50 ${ }^{+/ 46}$ Pim $1^{+/ D R-G F P}$ were infected with SceIIRES-hCD4 retrovirus, and $\mathrm{GFP}^{+}$cells were assessed $72 \mathrm{~h}$ after infection. The efficiency of $\mathrm{GFP}^{+}$is measured relative to the infectedonly $\left(\mathrm{CD}^{+}\right)$cells. Experiments were done in triplicate with two independent cell lines per genotype. $P$-value was determined by Wilcoxon rank-sum test. $(F)$ SV40-immortalized MEFs of the indicated genotypes were left untreated $(t=0)$ or irradiated with 2 Gy IR, and the levels of pS1987-ATM and $\gamma \mathrm{H} 2 \mathrm{AX}$ were assessed in the indicated time points.

signaling, as observed previously in $R a d 50^{S / S}$ mice (and yeast) (Usui et al. 2006), and thereby exhibited indices of ATM activation at levels disproportional to the extent of DNA damage. This latter interpretation predicts that Rad $50^{46}$ phenotypes would be ATM-dependent.

\section{The Rad50 $0^{+/ 46}$ phenotype is ATM-dependent}

Precedent for the hypothesis that $\operatorname{Rad} 50^{+/ 46}$ phenotypes could be ATM-dependent comes from $R a d 50^{S / S}$ mice, which at both the cellular and organismal levels exhibited phenotypes reminiscent of Rad50 $0^{+/ 46}$ (Bender et al. 2002; Morales et al. 2005). We found that most aspects of the Rad50 ${ }^{+/ 46}$ pathology, including hydrocephalus (Fig. 2B), were rescued in the context of Atm heterozygosity, demonstrating the acute ATM dependence of the Rad50 5 +/46 phenotype.

Mre11 complex-dependent ATM signaling affects the viability and proliferative behavior of $\mathrm{Lin}^{-} \mathrm{Scal}^{+} \mathrm{c}-\mathrm{Kit}^{+}$ (LSK) cells, which contain primitive hematopoietic compo- nents, including hematopoietic stem cells (HSCs) and lineage progenitors (Morales et al. 2008). Rad50 $0^{+/ 46}$ mice showed an altered LSK population characterized by an expansion (average increase of 4.7 -fold) of the multipotent precursors (MPPs) (Fig. 3A). This phenotype was also dependent on ATM because it was suppressed in $\mathrm{Rad}_{50}^{+/ 46} \mathrm{Atm}^{+/-}$mice (Fig. 3A). The increased MPP population was not correlated with elevated levels of its proximal descendants, the common lymphoid progenitor (CLP) and common myeloid progenitors (CMPs) (Fig. 3B). CFU-S assays, which measure the ability of MPPs to differentiate and form colonies in the spleen of lethally irradiated mice, were carried out (Spangrude et al. 1988). We noted a 50\% reduction in the colony-forming ability of Rad50 $0^{+/ 46} \mathrm{MPP}$ cells (Fig. 3C). These data indicate that the expanded Rad50 $0^{+/ 46}$ MPP population is not fully functional.

A remarkable outcome in $\operatorname{Rad} 50^{S / S} \mathrm{Atm}^{-1-}$ mice was the suppression of lymphomagenesis associated to ATM deficiency (Morales et al. 2005; Usui et al. 2006). Similarly, the latency of thymic lymphomas typical of the 
A

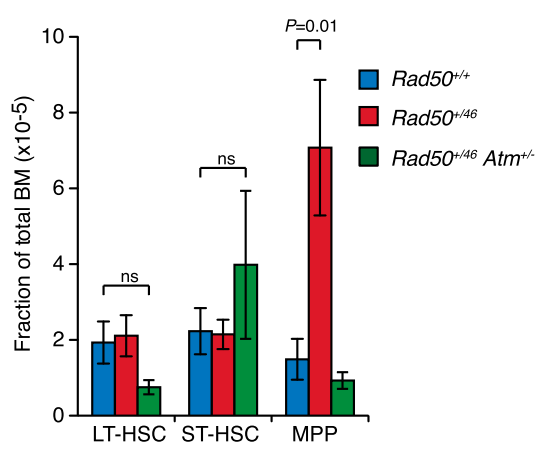

C

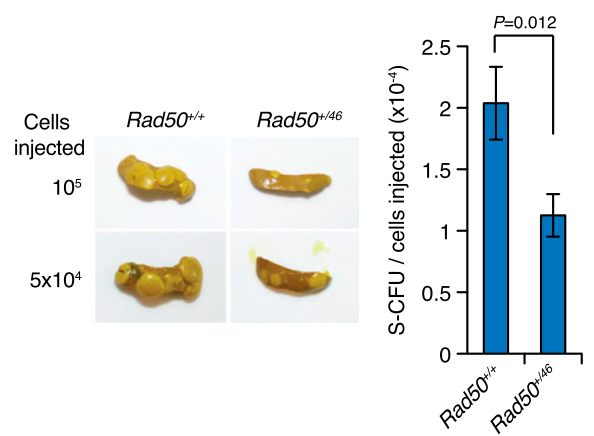

B

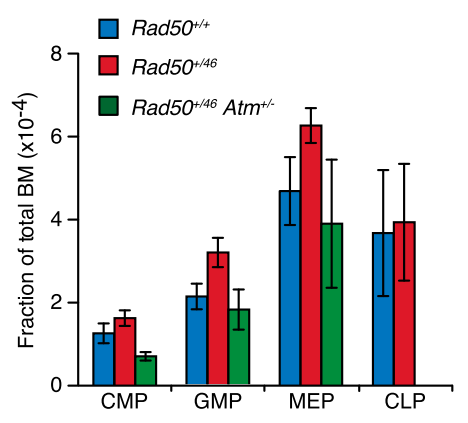

D

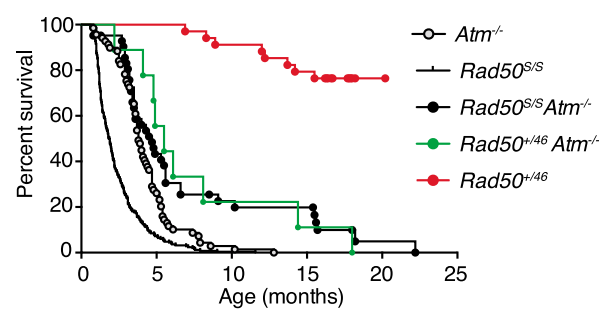

Figure 3. ATM-dependent hematopoietic alterations in $R a d 50^{+/ 46}$ mice. (A) Quantification of long-term hematopoietic stem cells (LTHSC), short-term hematopoietic stem cells (ST-HSC), and MPPs in bone marrow from mice of the indicated genotypes. Bars denote the average \pm standard error of mean (SEM). Rad50 $0^{+/}, n=8 ; \operatorname{Rad}_{50}^{+/ 46}, n=8, \operatorname{Rad}_{50^{+/ 46}} \mathrm{Atm}^{+/-}, n=2$. (B) Quantification of CMP, granulocyte macrophage progenitor (GMP), megakaryocyte erythroid progenitor (MEP), and CLP. Bars denote the average \pm SEM. $\operatorname{Rad}_{50}^{+/+}, n=5 ; \operatorname{Rad}^{+/ 46}, n=5 ; \operatorname{Rad}^{+/ / 46} \mathrm{Atm}^{+/-}, n=2$. $P$-values were determined by unpaired $t$-test. $(C)$ Representative images and quantification of CFU-S assay at day 13 using bone marrow cells of the indicated genotype. Bars denote the average \pm SEM of all the spleens obtained from three independent experiments. Rad50 ${ }^{+/+}, n=21 ; R^{2} 50^{+/ 46}, n=20$; Rad50 $0^{+/ 46} \mathrm{Atm}^{+/-}, n=5$. P-values were determined by unpaired $t$-test. (D) Kaplan-Meier survival curves of $\mathrm{Atm}^{-/-}$, Rad50 ${ }^{S / S}$, Rad50 ${ }^{S / S} \mathrm{Atm}^{-/-}$(previously published; Morales et al. 2005), Rad50 $0^{+/ 46}$, and $\operatorname{Rad}_{50}^{+/ 46} \mathrm{Atm}^{-1-}$ mice. Rad50 $0^{+/ 46}$ mouse survival was not assessed beyond 18 mo, and thus the events were censored at that age.

$\mathrm{Atm}^{-/-}$genoytpe was markedly increased in $\mathrm{Rad} 5 \mathrm{O}^{+/ 46}$ $\mathrm{Atm}^{-1-}$ mice (Fig. 3D). In light of recent data suggesting a role for the Mre11 complex in ATR activation (Duursma et al. 2013; Shiotani et al. 2013), the suppression of lymphomagenesis in $\mathrm{Rad}_{50} \mathrm{O}^{+/ 46} \mathrm{Atm}^{-1-}$ mice may reflect compensatory Mre11 complex-dependent ATR activation.

\section{Germ cell dysfunction in Rad50 $0^{+/ 46}$ mice}

Rad $50^{+/ 46}$ mice exhibited severe fertility defects. All males and $27 \%$ of the females were infertile, and the remaining $\mathrm{Rad}_{50^{+/ 46}}$ females produced fewer and smaller litters than

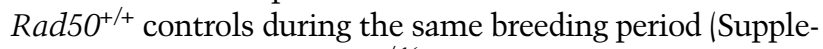
mental Fig. S5A,B). Rad50 $0^{+/ 46}$ exhibited ovarian and testicular atrophy (Fig. 4A,B), and the seminiferous tubules displayed severely reduced cellularity (Fig. 4C). As with the hematopoietic phenotype, testicular defects were ATM-dependent. Testes from $\mathrm{Rad} 50^{+/ 46} \mathrm{Atm}^{+/-}$mice were twofold larger than those from Rad50 ${ }^{+/ 46}$ (Fig. 4A), and the cellularity of the seminiferous tubules was increased (Fig. 4C).

Immunohistochemical staining for the synaptonemal complex protein SYCP3 revealed that $\operatorname{Rad} 50^{+/ 46}$ mice showed an eightfold reduction in meiotic prophase cells per tubule (Fig. 4C,D). Similar analyses revealed a 23-fold reduction in SYCP3-positive cells from 14-dpp Rad50 $0^{+/ 46}$ mice (Supplemental Fig. S5C,D). TUNEL staining of $\mathrm{Rad} 50^{+/ 46}$ tubules from adult and juvenile mice was unremarkable (Fig. 4C,D; Supplemental Fig. S5C,D), suggesting that the reduction in $\mathrm{Rad} 50^{+/ 46}$ meiotic cells was not due to apoptotic attrition. The reduction in cellularity did not appear to reflect a stage-specific block in meiotic progression, as chromosome spreads from the rare meiotic cells present revealed spermatocytes in all stages of meiosis (Supplemental Fig. S5E).

Spo11 protein initiates meiotic recombination by forming DSBs through a covalent protein-DNA intermediate. Spol1 is cleaved from DSB ends to liberate Spo11-oligonucleotide complexes (Neale et al. 2005) by a process that in yeast requires activity of the Mrel1 complex (Neale et al. 2005; Milman et al. 2009). In S. cerevisiae rad50-46 mutants, DSBs are formed, but Spo11 remains covalently bound to genomic DNA (M Hohl, C Tous, T Kochańczyk, A Krężel, A Aguilera, and JHJ Petrini, in prep.). We tested whether a defect in removal of Spol1 from DSB ends accounted for the infertility of $\mathrm{Rad} 50^{+/ 46}$ 
Roset et al.

A
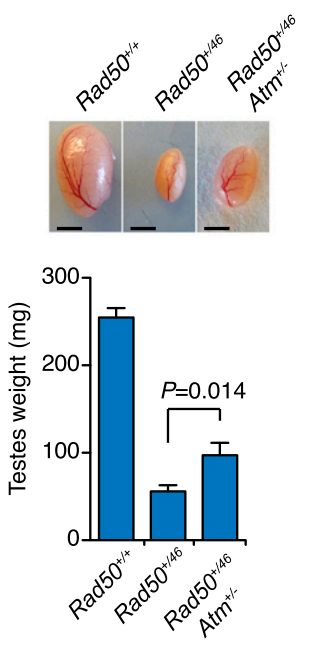

B
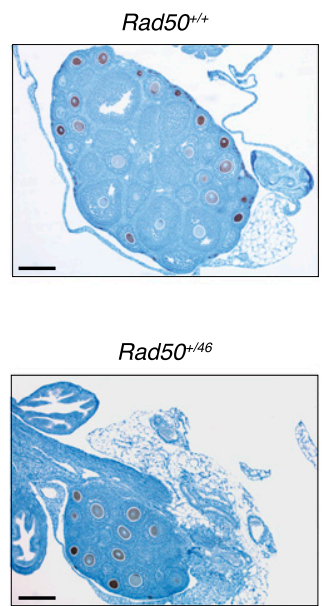

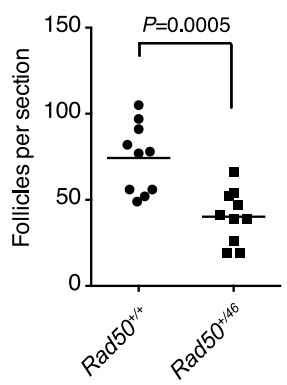

D

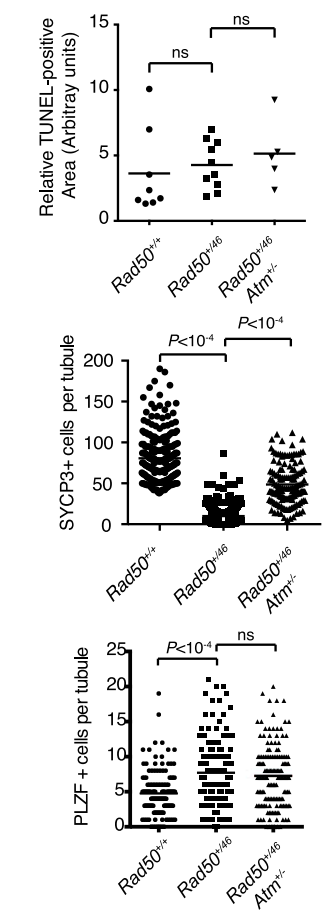

C

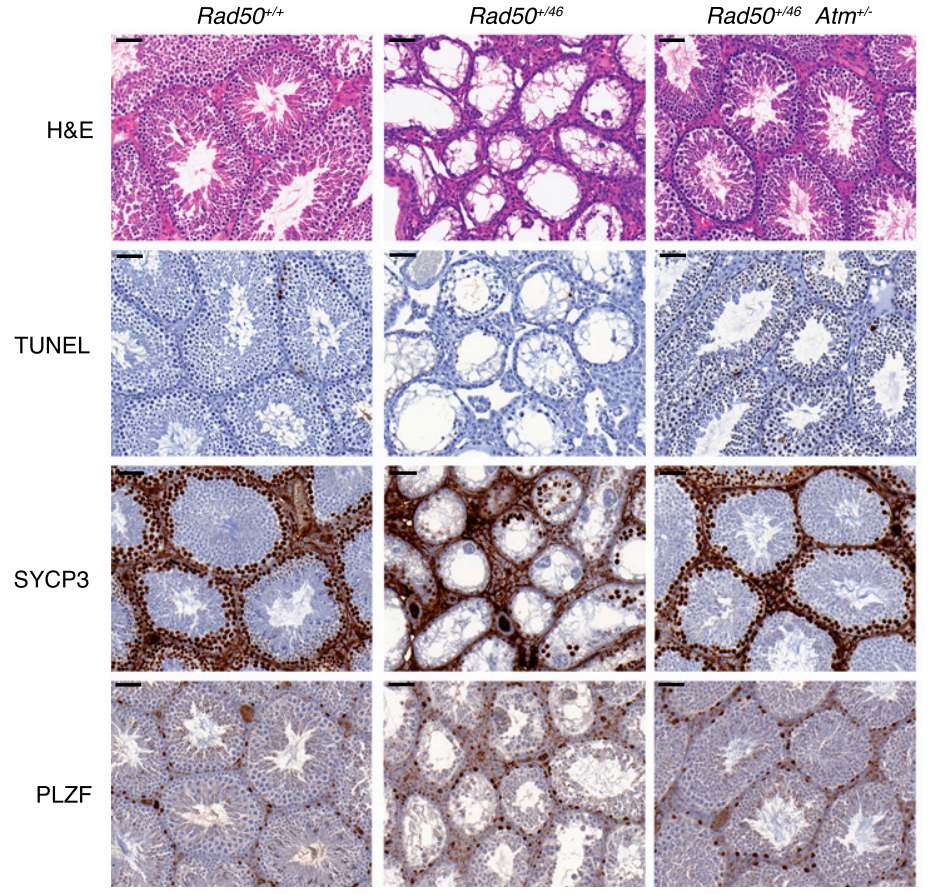

Figure 4. Germ cell dysfunction in Rad50 $0^{+/ 46}$ mice. $(A)$ Representative images of testis from mice of the indicated genotypes and average testes weight $\pm \operatorname{SEM}\left(\operatorname{Rad} 50^{+/+}, n=7\right.$; Rad50 $\left.{ }^{+/ 46}, n=8 ; \operatorname{Rad}_{50}^{+/ 46}, \mathrm{Atm}^{+/-} n=5\right)$. Bar, $2.5 \mathrm{~mm}$. $(B)$ Representative images of antiVASA-stained mid-ovary sections from 3-wk-old mice and quantification of the number follicles. Bar, 0.4 mm. Ovaries analyzed: $n=10$. $P$-value was determined by unpaired $t$-test. $(C)$ Hematoxylin and eosin (H\&E), TUNEL, SYCP3, and PLZF immunohistochemical staining of testis sections from adult mice of the indicated genotypes. Bar, $50 \mu \mathrm{m}$. $(D)$ Quantification of immunohistochemical staining from $C$. The TUNEL-positive area is expressed as a ratio to the total testis area. Testis analyzed: $\operatorname{Rad} 50^{+/+}, n=8 ; R a d 50^{+/ 46}, n=10$; Rad50 $0^{+/ 46} \mathrm{Atm}^{+/-}, n=5$. $P$-values were determined by unpaired $t$-test.

mice. Spo11-oligonucleotide complexes were nearly absent in adult and juvenile $\mathrm{Rad} 5 \mathrm{O}^{+/ 46}$ mice (Supplemental Fig. S5F). The reduction in Spo11-oligonucleotide complexes in Rad50 $0^{+/ 46}$ testes was not simply a consequence of testicular atrophy because they were evident in $D m c 1^{-/-}$ testes, which, like $\mathrm{Rad}_{50^{+/ 46}}$, are severely atrophic (Supplemental Fig. S5F). These data suggested that in Rad50+/46 mice, meiotic DSBs are not created, or Spo11 is not released following DSB formation. We could not exclude the possibility that this effect is due to the paucity of meiotic cells in $\mathrm{Rad} 50^{+/ 46}$ testes. To directly address whether defects in the formation or repair of meiotic DSBs were the cause of infertility of $R a d 50^{+/ 46}$ mice, we generated Rad50 ${ }^{+/ 46}$ Spo11 ${ }^{-1-}$ mice. Seminiferous tu- 
bules from $\mathrm{Rad}_{50^{+/ 46}}$ mice showed reduced cellularity compared with Spo11 ${ }^{-/-}$(Supplemental Fig. S5G). Analysis of sections from $\mathrm{Rad} 50^{+/ 46} \mathrm{Spo11^{-/- }}$ mice revealed that Rad50 ${ }^{+/ 46}$ was epistatic to Spo11 ${ }^{-/-}$. This result indicated that the $\operatorname{Rad} 50^{+/ 46}$ phenotype was independent of Spo11 and thus excluded the possibility of impaired Spol1 removal as a cause of $\operatorname{Rad} 50^{+/ 46}$ infertility.

These data suggest that the $\operatorname{Rad} 50^{+/ 46}$ defect was manifest prior to initiation of the meiotic program. Supporting that interpretation, $\mathrm{Rad} 50^{+/ 46}$ tubules displayed 1.6-fold more cells positive for PLZF (a marker of undifferentiated spermatogonia) (Buaas et al. 2004; Costoya et al. 2004) compared with $\mathrm{Rad} 5 \mathrm{O}^{+/+}$mice (Fig. 4C,D). This expansion of primitive precursors together with the reduction of meiotic cells and the lack of increased cell death was consistent with a block in spermatogonial differentiation, analogizing the block observed in primitive hematopoietic precursors.

Mre11 complex and ATM activation in $\operatorname{Rad} 50^{46 /-}$ cells Rad5046/ind and Rad50 ${ }^{\text {/ind }}$ MEFs and ear fibroblast (EF) cultures were established. Lentiviral-mediated delivery of Cre resulted in excision within the Rad50 ind allele in 3 d (Supplemental Fig. S6A) to produce $\operatorname{Rad}_{50}{ }^{\Delta /-}$ and Rad50 $0^{46 /-}$ cells that could be maintained in culture for 7-8 d after Cre infection. This provided a window of time to assess the outcome of limiting cells to $\operatorname{Rad} 50^{46}$ as the sole source of Rad50 protein. As shown previously in Rad50 ${ }^{\Delta /-}$ cell extracts (Adelman et al. 2009), Rad50 $46 /-$ cells displayed decreased levels of Rad50, Mre11, and Nbs1 (Fig. 5A), suggesting that Mre11 complex proteins were less stable in Rad50 ${ }^{46 /-}$ cells.

Acute disruption of the Mre11 complex results in a dramatic increase in chromosomal aberrations (Demuth et al. 2004; Frappart et al. 2005; Reina-San-Martin et al. 2005; Yang et al. 2006; Adelman et al. 2009). Excision in the Rad50 ind allele in Rad50 46/ind cells produced a similar outcome, with $53 \%$ of $\operatorname{Rad} 50^{\Delta /-}$ and $42 \%$ of $\operatorname{Rad} 50^{46 /-}$ cells showing chromosomal aberrations compared with $12 \%$ of Rad50 ${ }^{+/-}$(Fig. 5B). Cells with multiple aberrations (three or more) were not seen in Rad50 ${ }^{+/-}$controls but represented up to $30 \%$ and $11.8 \%$ in $\operatorname{Rad}_{50}{ }^{\mathrm{A}-\mathrm{-}}$ and $\mathrm{Rad} 50^{46 /-}$, respectively (Supplemental Fig. S6B).
A

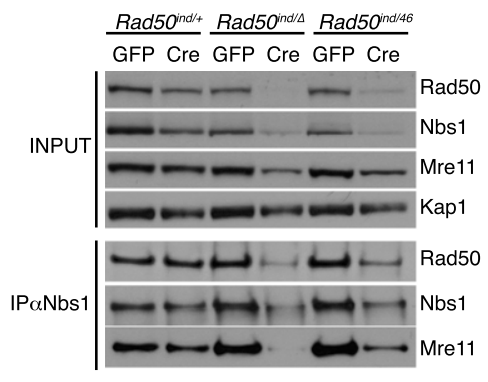

B

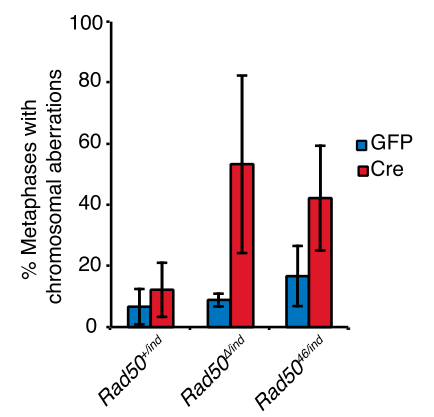

C

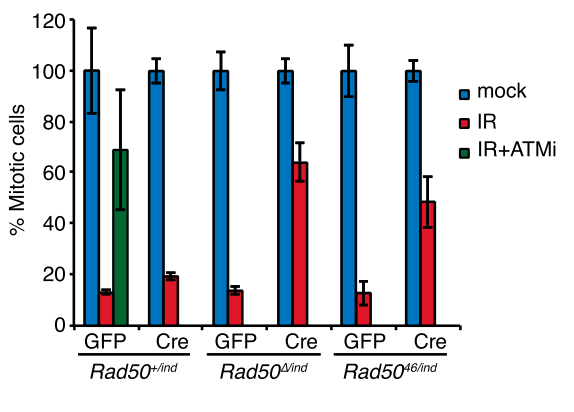

D

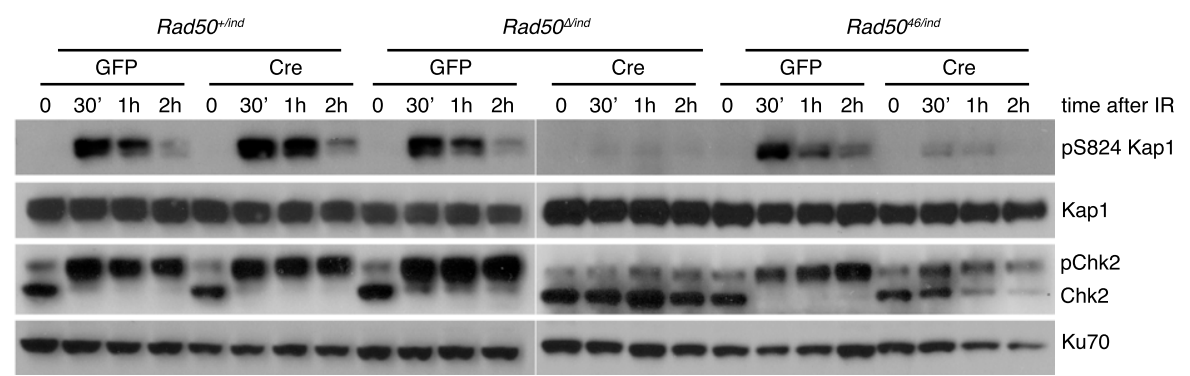

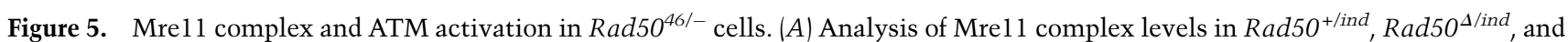
Rad50 ${ }^{46 / i n d}$ SV40-immortalized MEFs $8 \mathrm{~d}$ after the lentiviral delivery of Cre or GFP and Nbs1 immunoprecipitation to assess the Mre11

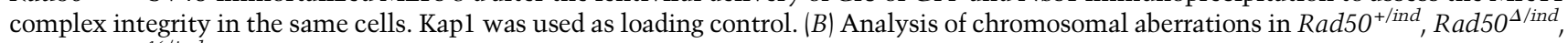
and Rad50 46/ind SV40-immortalized MEFs $8 \mathrm{~d}$ after the lentiviral delivery of Cre or GFP. Shown is average \pm SD of three independent experiments. Twenty-five or more metaphases were scored per genotype and experiment. (C) Analysis of the G2/M checkpoint in Rad50 ${ }^{+/ i n d}, R_{1} 50^{4 / \text { ind }}$, and Rad50 ${ }^{46 / \text { ind }}$ SV40-immortalized MEFs $8 \mathrm{~d}$ after the lentiviral delivery of Cre or GFP. Mitotic cells were determined in mock-treated cells or $1 \mathrm{~h}$ after 5 Gy IR by measuring the phospho-Ser10 Histone H3-positive cells. The ATM inhibitor KU-55933 was added $2 \mathrm{~h}$ before IR treatment and kept throughout the experiment. Shown is average mitotic ratio relative to mock-treated \pm SD of two independent experiments done in triplicate. $(D)$ Analysis of pS824-Kap1 and Chk2 phosphorylation in Rad50 ${ }^{+/ i n d}$, Rad50 4 /ind , and Rad50 $46 /$ ind SV40-immortalized MEFs $8 \mathrm{~d}$ after the lentiviral delivery of Cre or GFP after 2 Gy of $\gamma$ radiation. Time 0 corresponds to untreated cells. Note that Chk2 migrates as a higher-molecular-weight species when phosphorylated (pChk2). Ku70 levels were used as loading control. 
$\mathrm{Rad50}^{\Delta /-}$ MEFs were unable to activate ATM in response to IR, as evidenced by reduced phosphorylation of Kap1 and Chk2 following IR treatment (Fig. 5D). Rad50 MEFs were also impaired in ATM activation but to a lesser extent. Whereas phosphorylation of Kap1 and Chk2 was undetectable in $\mathrm{Rad} 50^{\Delta /-}$ MEFs, we could consistently detect it in Rad50 $46 /-$ MEFs (Fig. 5D). This suggests that Rad50 $46 /-$ cells retain a degree of Mre11 complex function; however, this observation may reflect the presence of residual wild-type Rad50 protein.

Reduced ATM activation in Rad50 $46 /-$ cultures was associated with impairment of the DNA damage-dependent G2/M checkpoint. One hour after 5 Gy of IR, cells with at least one copy of wild-type Rad50 showed an $80 \%-90 \%$ reduction in the mitotic cells, indicative of a proficient G2/M checkpoint (Fig. 5C). Excision in the Rad $50^{\text {ind }}$ allele to produce $R a d 50^{\Delta /-}$ or Rad50 $46 /-$ cells caused defects in the G2/M checkpoint, with cells exhibiting only a $36 \%$ and $52 \%$ reduction in the proportion of mitotic cells, respectively, after IR (Fig. 5C).

\section{$\operatorname{Rad} 50^{46}$ promotes tumorigenesis}

The Mre11 complex has been implicated in the suppression of malignancy in several contexts (Stracker and Petrini 2011; Foster et al. 2012; Gupta et al. 2013). Accordingly, cohorts of $30 \mathrm{Rad} 50^{+/ 46}, 31 \mathrm{Rad} 50^{+/ N e o 46}$, and $34 \mathrm{Rad}_{5 \mathrm{O}^{+/+}}$mice were followed for $18 \mathrm{mo}$. Although no signs of morbidity were evident, multiple liver neoplasms were noted upon necropsy. The incidence was $26 \%$ in $\mathrm{Rad} 50^{+/ \mathrm{Ne} 46}$ mice, $37 \%$ in $\mathrm{Rad} 50^{+/ 46}$ mice, and $3 \%$ in $\mathrm{Rad}_{50^{+/+}}$mice (Fig. 6A). Most of the affected mice presented hyperplastic nodules and/or adenomas, but $10 \%$ of $\mathrm{Rad} 50^{+/ 46}$ mice developed malignant hepatoblas-

A

\begin{tabular}{|c|c|c|c|}
\hline & $\operatorname{Rad} 50^{+4+}$ & $\operatorname{Rad} 50^{+146}$ & Rad50+Noout6 \\
\hline & $1(2.9 \%)$ & $8(26.7 \%)^{* *}$ & $7(22.6 \%)^{\star}$ \\
\hline Adenomas & $1(2.9 \%)$ & $8(26.7 \%)^{* *}$ & $6(19.4 \%)^{*}$ \\
\hline Hepatoblas & $0(0.0 \%)$ & $3(10 \%)$ & $3(9.7 \%)$ \\
\hline Combined liver malignancy & $1(2.9 \%)$ & $11(36.7 \%)^{\star \star \star \star}$ & $8(25.8 \%)^{\star \star}$ \\
\hline
\end{tabular}

B

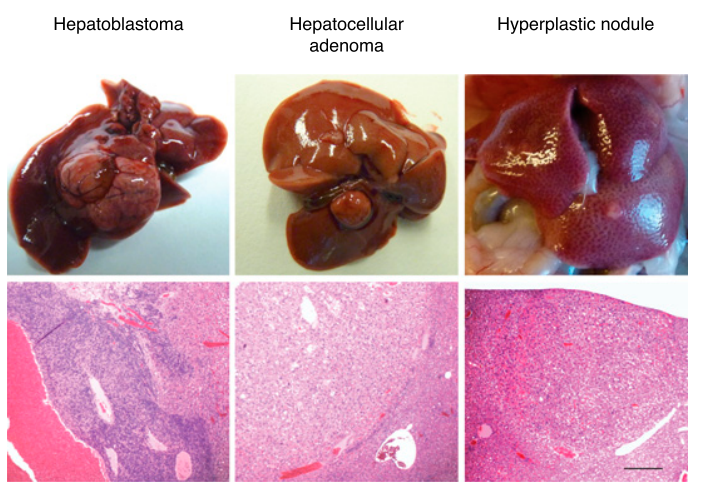

Figure 6. $R a d 50^{+/ 46}$ and $R a d 50^{+/ N e o 46}$ mice develop liver tumors. (A) Frequency of liver tumors developed by $R a d 50^{+/+}$, Rad50 $0^{+/ 46}$, and Rad50 $0^{+/ N e o 46}$ mice by 18 mo of age. P-values were calculated with Fisher's exact test comparing with $\mathrm{Rad}_{50}^{+/+}$. $\left.{ }^{\star}\right) P \leq 0.05 ;\left(^{\star \star}\right) P \leq 0.01 ;\left(^{\star \star \star}\right) P \leq 0.001$. $(B)$ Representative images and H\&E staining of the hepatic tumors developed by $\mathrm{Rad}_{50}^{+/ 46}$ and Rad50 ${ }^{+/ N e o 46}$ mice. Bar, $200 \mu \mathrm{m}$ for all images. toma (Fig. 6A,B). Unlike adenomas, which arise from mature hepatocytes, hepatoblastomas arise from hepatic progenitor cells of the portal areas (Marquardt and Thorgeirsson 2010). This indicates that both differentiated hepatocytes and immature progenitors are susceptible to Rad $50^{46}$-induced malignancy.

\section{Discussion}

We showed previously that alteration of either invariant cysteine of the $S$. cerevisiae Rad50 hook domain results in complete inactivation of Rad50, limiting the ability to distinguish hook-specific from general Mre11 complex functions (Hopfner et al. 2002). The residues between the cysteines are also nearly invariant. The first is either Pro $(85 \%)$ or $\operatorname{Tyr}(10 \%)$, and the second position contains Leu or Val in $80 \%$ of the cases (Stracker and Petrini 2011). In this study, the functional significance of the Rad50 hook domain in the mammalian Mre11 complex was examined through the generation of mouse mutants affecting those residues. Neither of the hook mutants encoded gene products that support viability at the organismal or cellular level, indicating that, as in $S$. cerevisiae, the hook domain is required for Mre11 complex function in mammals. In the heterozygous configuration, we found that $\operatorname{Rad} 50^{46}$ and $\operatorname{Rad} 50^{47}$ behaved as dominant gain-of-function alleles that promoted chronic DDR signaling. These outcomes at the molecular level were associated with severe phenotypes in vivo, including embryonic lethality, hydrocephalus, defects in the development and maintenance of primitive cells of the bone marrow and germline, and increased incidence of liver neoplasms.

\section{$\operatorname{Rad} 50^{46}$ is not a loss-of-function allele}

Despite the phenotypic severity observed, the data are inconsistent with $\operatorname{Rad} 50^{46}$ being a null allele. First, the phenotypes in Rad50 ${ }^{46 /-}$ cells are milder than $\mathrm{Rad}_{50}{ }^{\mathrm{I}-}$. Although perdurance of wild-type Rad50 protein following Cre-mediated deletion in Rad50 ${ }^{46 / \text { ind }}$ cultures cannot be excluded, Rad50 46 may retain limited functionality. Second, $\operatorname{Rad} 50^{46}$ exerts dose-dependent dominance; the phenotype of $\mathrm{Rad} 5 \mathrm{O}^{+/ \mathrm{NeO} 46}$, in which expression of the mutant gene is lower than in $\operatorname{Rad}_{50} 0^{/ 46}$, was less severe. In contrast, $\mathrm{Rad} 50^{+/ \Delta}$ mice and cells are indistinguishable from wild-type (CF Bender, CA Adelman, and JHJ Petrini, unpubl.). Hence, the observed phenotypes do not simply reflect reduced dosage of wild-type Rad50. Finally, genetic ablation of Rad50 in the liver is not associated with detectable pathology (Adelman et al. 2009), whereas liver neoplasia and liver tumors were common in $\operatorname{Rad} 50^{+/ 46}$ mice.

Given that mutations in $\operatorname{Rad} 50^{46}$ and $\operatorname{Rad} 50^{47}$ affect one of the Mre11 complex's dimerization domains, it is likely that the dominant behavior of these alleles results from interaction of the mutant gene product with the wild-type Rad50 protein. Supporting this hypothesis, we found that Rad50 ${ }^{\mathrm{WT}}$ and Rad50 ${ }^{46}$ hook domains interact in vitro (Supplemental Fig. S7). In principle, Rad50 
cells could contain wild-type homodimers, mutant/wildtype heterodimers, and mutant homodimers. The Rad50 ${ }^{+/ 46}$ phenotypes observed are likely attributable to heterotypic complexes. Several lines of evidence indicate that alterations of the hook domain exert global effects on Mre11 complex function (Hopfner et al. 2002; Wiltzius et al. 2005; Hohl et al. 2011). The data presented here further suggest that these effects can be exerted in trans within the dimeric assembly of the complex.

\section{Chronic DDR signaling}

Rad50 $0^{+/ 46}$ and $R a d 50^{+/ 47}$ cells exhibit constitutive $\gamma \mathrm{H} 2 \mathrm{AX}$ formation. However, $R a d 50^{+/ 46}$ cells exhibited only a modest reduction in HDR efficiency and a slight sensitivity to camptothecin and did not show increased spontaneous chromosomal aberrations. These facts are inconsistent with spontaneous DNA damage as the cause of $\gamma \mathrm{H} 2 \mathrm{AX}$ formation and suggest the possibility that Rad50 $0^{+/ 46}$ behaves as a hypermorph with respect to DNA damage signaling, as previously observed for the Rad50S allele (Usui et al. 2006). Although the underlying mechanisms of Mre11 complex-dependent DDR regulation remain unclear, the increased latency of lymphomas in Rad50 $\mathrm{Atm}^{-/-}$mice supports this interpretation.

The $\operatorname{Rad} 50^{S}$ and $\operatorname{Rad} 50^{46}$ mutations affect domains widely separated yet engender similar DDR signaling phenotypes $\left(\operatorname{Rad} 50^{S}\right.$ is the K20M substitution). AFM studies have shown that DNA binding by the globular domain promotes spatial reorganization of the coiled-coil and hook domain (Moreno-Herrero et al. 2005). Conversely, Rad50 $0^{+/ 46}$ and $\operatorname{Rad} 50^{+/ 47}$ mutations as well as mutations that truncate the Rad50 coiled-coil domain affect functions that are likely specified within the globular domain (Hohl et al. 2011). These data illustrate the functional interdependence of the hook and globular domains within the Mre11 complex.

\section{The Rad50 $0^{+/ 46}$ phenotype and progenitor cells}

Consistent with the interpretation that the $\mathrm{Rad} 50^{46}$ allele chronically activates ATM, the phenotypic outcomes in Rad50 $0^{+/ 46}$ mice are dependent on Atm. Again, this situation is comparable with $\operatorname{Rad} 50^{S / S}$ mice, and the tissues primarily affected are the same: primitive cells in the hematopoietic and germline lineages. These observations indicate that the Mre11-ATM-dependent signaling pathway is important for the maintenance and function of primitive cells in the bone marrow and germline (Morales et al. 2008; Takubo et al. 2008; Maryanovich et al. 2012). The Mre11 complex-ATM signaling axis likely affects progenitor cells in other organs systems (Shiloh and Ziv 2013). For example, hyperpigmentation, common to both Rad $50^{S / S}$ and $\operatorname{Rad} 50^{+/ 46}$, has also been observed in mice with chronic DDR signaling in the skin due to telomere dysfunction (Hockemeyer et al. 2008; He et al. 2009; Martinez et al. 2010) or DNA repair defects (Zhang et al. 2011). In those instances, melanocyte expansion appears to occur in response to epidermal stem cell depletion (Stout and Blasco 2009).

\section{Tumorigenesis in $\operatorname{Rad} 50^{+/ 46}$ mice}

Roughly a quarter $(26.7 \%)$ of $R a d 50^{+/ 46}$ mice developed hepatocellular adenomas that were frequently coincident with additional preneoplastic lesions, primarily hyperplastic nodules and areas of disorganized architecture. The Mre11 complex-ATM pathway has been previously implicated in liver cancer, as Atm is required for diethylnitrosamine-induced liver carcinogenesis (Teoh et al. 2010). Notably, almost one-third of the tumor-bearing mice developed hepatoblastoma, a rare tumor that in humans primarily affects infants and children. The blastic and undifferentiated character of this tumor suggests that it arises from hepatic progenitor cells of the portal areas (Marquardt and Thorgeirsson 2010). This outcome represents an additional instance in which Mre11 complex-ATM signaling affects homeostasis by affecting progenitor cells.

Mre11 complex mutations have been identified in $\sim 4 \%$ of human tumors (data from cBioPortal; Cerami et al. 2012). The observation here of dominant Rad50 mutations promoting tumorigenesis supports the possibility that heterozygous Mre11 complex mutations may underlie tumor development, a possibility that should be considered in the genomic analysis of tumors.

\section{Materials and methods}

\section{Rad50-HK expression, purification, and analysis}

6xHis-SMT3-tagged Rad50-HK proteins (amino acids 591-773) were expressed in Escherichia coli. Soluble extracts were prepared in $\mathrm{HK}$ buffer $(200 \mathrm{mM} \mathrm{NaCl}, 50 \mathrm{mM}$ Tris at $\mathrm{pH} 7.5,0.2 \%$ NP-40, 10\% glycerol, $0.5 \mathrm{mM}$ DTT) plus protease and phosphatase inhibitors and was purified by nickel-chelating affinity chromatography followed by Ulp1 protease treatment and a second nickel-chelating affinity purification step to separate the 6xHis-SMT3 tag. Rad50-HK proteins were analyzed by SEC using a 24-mL Superdex 200 column equilibrated with $20 \mathrm{mM}$ Tris (pH 7.6), $500 \mathrm{mM} \mathrm{NaCl}, 0.1 \mathrm{mM}$ EDTA, and 2 mM DTT.

SEC-MALS was performed as described (Rambo and Tainer 2010) with a size exclusion column equilibrated with $20 \mathrm{mM}$ Tris (pH 7.6), $500 \mathrm{mM} \mathrm{NaCl}, 0.1 \mathrm{mM}$ EDTA, and $1 \mathrm{mM}$ tris(2carboxyethyl/phosphine. MALS experiments were performed using an 18-angle DAWN HELEOS light-scattering detector connected in tandem to an Optilab refractive index concentration detector (Wyatt Technology). Metal concentrations were measured using a quadrupole-based ICP-MS (7500ce, Agilent Technologies) equipped with a MicroMist nebulizer (Agilent Technologies).

\section{Gene targeting and mice}

The targeting vectors were constructed using the recombineering method previously described (Liu et al. 2003). Targeting was carried out via electroporation into the embryonic stem cell AC1 that had a 129/SvEv-background (gift of G. Oltz and E. Rhuley). Selection, clonal expansion, and analysis were performed using previously published procedures (Luo et al. 1999). Chimeras were generated at the SKI Transgenic Facility using standard methods, and male chimeras were crossed with C57BL6 mice to detect germline transmission. Rad50 $0^{+/ N e o 46}$ mice were mated with CAG-Cre transgenic mice (Sakai and Miyazaki 1997) to generate 
the $\mathrm{Rad} 50^{46}$ allele. All mice were maintained on mixed 129/SvEv and C57BL6 background.

Mice were housed in ventilated rack caging in a pathogen-free facility. The Institutional Animal Care and Use Committee of Memorial Sloan-Kettering Cancer Center approved animal use protocols. Atm ${ }^{-/-}$and Spo11 ${ }^{-/-}$mice were previously described (Barlow et al. 1996; Baudat et al. 2000).

\section{Cellular assays}

MEFs and EFs were generated, cultured, and immortalized as described (Bender et al. 2002). Rad50 ${ }^{+/ 47} \mathrm{EFs}$ were generated from Rad50 $0^{+/ N e o 47}$ chimeric mice by growing the cells in medium containing $1 \mathrm{mg} / \mathrm{mL}$ G418 followed by lentiviral delivery of Cre and clonal selection.

Western blots were carried out on $40 \mu \mathrm{g}$ of protein extracted with NTEN (20 mM Tris at pH 8, $150 \mathrm{mM} \mathrm{NaCl}, 1 \mathrm{mM}$ EDTA, $0.5 \%$ NP-40) plus protease and phosphatase inhibitors. For $\mathrm{H} 2 \mathrm{AX}$ blots, we used $3 \mu \mathrm{g}$ of the histone fraction extracted with $0.1 \mathrm{M} \mathrm{HCl}$ after a pre-extraction with NTEN. All of the antibodies were incubated overnight at $4^{\circ} \mathrm{C}$ in $5 \%$ milk. The antibodies used were rabbit anti-Rad50 polyclonal (custom Petrini laboratory antibody m84-7), rabbit anti-Nbs1 polyclonal (custom Petrini laboratory antibody 92-5), rabbit anti-Mre11 polyclonal (custom Petrini laboratory antibody 42-5), ATM (Cell Signaling), ATM pS1981 (Cell Signaling), $\gamma \mathrm{H} 2 \mathrm{AX}$ (Millipore), H2AX (Bethyl Laboratories), Kap1 pS824 (Abcam), Kap1 (Novus Biologicals), Chk2 (Clone 7, Millipore), and Ku70 (Santa Cruz Biotechnology).

For Nbs1 immunoprecipitation, cell extracts of SV40-immortalized MEFs were prepared with lysis buffer A $(300 \mathrm{mM} \mathrm{NaCl}$, $20 \mathrm{mM}$ Tris at $\mathrm{pH} 8.0,0.5 \%$ sodium deoxicholate, $1 \%$ Triton $\mathrm{X}-100,5 \mathrm{mM} \mathrm{MgCl}_{2}$ supplemented with protease and phosphatase inhibitors). Total protein $(0.5 \mathrm{mg})$ was incubated with $2 \mu \mathrm{L}$ of anti-Nbs1 antisera and protein A-agarose beads (Amersham) for $3 \mathrm{~h}$ at $4^{\circ} \mathrm{C}$, washed extensively, and eluted with Laemmli's buffer.

For colony-forming assays, cells were treated with the indicated clastogens and plated in triplicate, and colonies were assessed $10 \mathrm{~d}$ later by staining with crystal violet.

Metaphases were prepared from cultures treated with $2 \times 10^{-7} \mathrm{M}$ colcemid for $1 \mathrm{~h}$. Cells were harvested, hypotonically swelled with $0.075 \mathrm{M} \mathrm{KCl}$ for $15 \mathrm{~min}$ at $37^{\circ} \mathrm{C}$, fixed, washed in ice-cold 3:1 methanol:acetic acid, and dropped on slides. Slides were stained with $5 \%$ Giemsa (Sigma) for $10 \mathrm{~min}$ and rinsed with distilled water, and coverslips were mounted with Permount (Fisher). Images were captured using an Olympus IX60 microscope and imaged with a Hammamatsu CCD camera. More than 25 spreads were scored for each sample.

G2/M checkpoint was done as previously described (Theunissen and Petrini 2006).

Lentiviral production, concentration, and titering were carried out using previously described methods (Dull et al. 1998; Lois et al. 2002). For lentivirus-Cre and lentivirus-GFP infections, $5 \times 10^{4}$ cells were resuspended in $3 \mathrm{~mL}$ of DMEM supplemented with $10 \%$ CCS containing $5 \mu \mathrm{g} / \mathrm{mL}$ polybrene and lentivirus at a multiplicity of infection (MOI) 50. Twenty-four hours after infection, fresh medium was added, and cells were trypsinized and replated every $3 \mathrm{~d}$ to avoid confluency.

\section{DR-GFP assay}

Pim1 $1^{D R-G F P / D R \text {-GFP }}$ mice (Kass et al. 2013) were crossed with Rad50 $0^{+/ 46}$, and heterozygous Pim1 $1^{+/ D R-G F P} \operatorname{Rad} 50^{+/ 46}$ and Pim1 $1^{+/ D R-G F P}$ Rad $50^{+/+}$primary skin fibroblast cultures were established. To deliver I-SceI and monitor only the I-SceIexpressing cells, we inserted and IRES-hCD4 cassette into the retroviral vector pMX-ISceI (gift from Fred Alt). I-SceI-hCD4expressing retrovirus produced in Phoenix cells were used to infect primary cultures in the presence of $5 \mu \mathrm{g} / \mathrm{mL}$ polybrene for $24 \mathrm{~h}$. Seventy-two hours after the infection, cells were harvested, stained with anti-CD4 PE-Cy5 (BD-Pharmingen), and analyzed by flow cytometry. The number of GFP-positive cells was expressed as a ratio to the CD4-positive (infected) cells.

\section{Hematopoietic lineage analysis}

Hematopoietic lineages were determined as previously described (Brenet et al. 2013). Briefly, bone marrow single-cell suspensions prepared from both back legs were depleted of lineage-positive cells using a lineage cell depletion kit (Miltenyi Biotec) and simultaneously stained with different antibodies. Hematopoietic populations were identified as follows: long-term HSCs, $\mathrm{LKS}^{+}$ CD34 ${ }^{-}$Flk2 ${ }^{-}$; short-term HSCs, LKS $^{+}$CD34 ${ }^{+}$Flk2 ${ }^{-}$; MPPs, LKS $^{+}$ $\mathrm{CD}^{+} 4^{+} \mathrm{Flk2}^{+}$; $\mathrm{CMPs}, \mathrm{LKS}^{-} \mathrm{CD} 34^{+} \mathrm{FcR}^{\text {low }}$; granulocyte macrophage progenitors, $\mathrm{LKS}^{-} \mathrm{CD} 34^{+} \mathrm{FcR}^{+}$; and megakaryocyte erythroid progenitors, $\mathrm{LKS}^{-} \mathrm{CD} 34^{-} \mathrm{FcR}^{-}$. The CLP population was defined as $\mathrm{LKS}^{+}$Flk2 $2^{+}$, IL7R $\alpha^{+}$. DAPI was used to exclude dead cells during flow cytometric analysis.

MPPs were enumerated using the day 13 CFU-S assay. In brief, recipient mice were lethally irradiated and injected with bone marrow cells. Spleens were isolated $13 \mathrm{~d}$ after transplantation and fixed in Bouin's solution, and macroscopic colonies were counted.

\section{Histological sample preparation, staining, and analysis}

Tissue samples for histological analyses were fixed overnight at $4^{\circ} \mathrm{C}$ with $4 \%$ paraformaldehyde, rinsed, stored at $4^{\circ} \mathrm{C}$ in $70 \%$ ethanol, and then processed for paraffin embedding. Eightmicrometer sections were prepared, and slides were processed and stained at the Memorial Sloan-Kettering molecular cytogenetics core facility for hematoxylin and eosin (H\&E), TUNEL, anti-VASA, anti-SYCP3, and anti-PLZF.

H\&E-stained and immunohistochemically stained slides were digitally scanned using a Mirax scanner. TUNEL staining was quantified relative to the total area using standardized color filter settings in the Metamorph image analysis software. Anti-PLZFand anti-SYCP3-positive cells per tubule were manually scored from at least 25 tubules per testis.

\section{Acknowledgments}

We thank Maria Jasin for providing Pim $1^{D R-G F P}$ mice; Fred Alt for the pMX-ISceI plasmid; Linda Johnson and Julie White from the Center for Comparative Medicine and Pathology for assistance with pathological analysis; David Klimstra for help with liver pathology; members of the J.H.J.P. laboratory for critical reading of the manuscript, discussions, and helpful insight; Katelynd Vanness for technical assistance; and Thomas J. Kelly for critical reading of the manuscript. This work was supported by the following grants: RO1-GM56888 (to J.H.J.P.); National Cancer Institute CA159175 (to J.M.S.); National Heart, Lung, and Blood Institute (NHLBI) HL119872 (to J.M.S.); NHLBI HL055748 (to J.M.S.); P01 CA092584 (to J.A.T.); R01 CA117638 (to J.A.T); and R01 GM105421 (to Maria Jasin and S.K.). R.R. was supported in part by Fundación Alfonso Martín Escudero. J.L.V. is recipient of a fellowship from Le Fonds de la Recherche en Santé du Québec. J.M.S. is a Leukemia and Lymphoma Society Scholar. J.L. was supported in part by an American Cancer Society post-doctoral fellowship. 


\section{References}

Adelman CA, De S, Petrini JH. 2009. Rad50 is dispensable for the maintenance and viability of postmitotic tissues. Mol Cell Biol 29: 483-492.

Barlow C, Hirotsune S, Paylor R, Liyanage M, Eckhaus $M$, Collins F, Shiloh Y, Crawley JN, Ried T, Tagle D, et al. 1996. Atm-deficient mice: A paradigm of ataxia telangiectasia. Cell 86: 159-171.

Baudat F, Manova K, Yuen JP, Jasin M, Keeney S. 2000. Chromosome synapsis defects and sexually dimorphic meiotic progression in mice lacking Spol1. Mol Cell 6: 989-998.

Bender CF, Sikes ML, Sullivan R, Huye LE, Le Beau MM, Roth DB, Mirzoeva OK, Oltz EM, Petrini JH. 2002. Cancer predisposition and hematopoietic failure in $\operatorname{Rad} 50(\mathrm{~S} / \mathrm{S})$ mice. Genes Dev 16: 2237-2251.

Brenet F, Kermani P, Spektor R, Rafii S, Scandura JM. 2013. TGF $\beta$ restores hematopoietic homeostasis after myelosuppressive chemotherapy. I Exp Med 210: 623-639.

Bressan DA, Baxter BK, Petrini JH. 1999. The Mre11-Rad50-Xrs2 protein complex facilitates homologous recombinationbased double-strand break repair in Saccharomyces cerevisiae. Mol Cell Biol 19: 7681-7687.

Buaas FW, Kirsh AL, Sharma M, McLean DJ, Morris JL, Griswold MD, de Rooij DG, Braun RE. 2004. Plzf is required in adult male germ cells for stem cell self-renewal. Nat Genet 36: 647-652.

Cerami E, Gao J, Dogrusoz U, Gross BE, Sumer SO, Aksoy BA, Jacobsen A, Byrne CJ, Heuer ML, Larsson E et al. 2012. The cBio cancer genomics portal: An open platform for exploring multidimensional cancer genomics data. Cancer discovery 2: 401-404.

Costoya JA, Hobbs RM, Barna M, Cattoretti G, Manova K, Sukhwani M, Orwig KE, Wolgemuth DJ, Pandolfi PP. 2004. Essential role of Plzf in maintenance of spermatogonial stem cells. Nat Genet 36: 653-659.

de Jager M, van Noort J, van Gent DC, Dekker C, Kanaar R, Wyman C. 2001. Human Rad50/Mre11 is a flexible complex that can tether DNA ends. Mol Cell 8: 1129-1135.

de Jager M, Trujillo KM, Sung P, Hopfner KP, Carney JP, Tainer JA, Connelly JC, Leach DR, Kanaar R, Wyman C. 2004. Differential arrangements of conserved building blocks among homologs of the Rad50/Mre11 DNA repair protein complex. J Mol Biol 339: 937-949.

Demuth I, Frappart PO, Hildebrand G, Melchers A, Lobitz S, Stockl L, Varon R, Herceg Z, Sperling K, Wang ZQ, et al. 2004. An inducible null mutant murine model of Nijmegen breakage syndrome proves the essential function of NBS1 in chromosomal stability and cell viability. Hum Mol Genet 13: 2385-2397.

Dull T, Zufferey R, Kelly M, Mandel RJ, Nguyen M, Trono D, Naldini L. 1998. A third-generation lentivirus vector with a conditional packaging system. J Virol 72: 8463-8471.

Duursma AM, Driscoll R, Elias JE, Cimprich KA. 2013. A role for the MRN complex in ATR activation via TOPBP1 recruitment. Mol Cell 50: 116-122.

Foster SS, De S, Johnson LK, Petrini JH, Stracker TH. 2012. Cell cycle- and DNA repair pathway-specific effects of apoptosis on tumor suppression. Proc Natl Acad Sci 109: 9953-9958.

Frappart PO, Tong WM, Demuth I, Radovanovic I, Herceg Z, Aguzzi A, Digweed M, Wang ZQ. 2005. An essential function for NBS1 in the prevention of ataxia and cerebellar defects. Nat Med 11: 538-544.

Gonzalez-Barrera S, Cortes-Ledesma F, Wellinger RE, Aguilera A. 2003. Equal sister chromatid exchange is a major mech- anism of double-strand break repair in yeast. Mol Cell 11: 1661-1671.

Gupta GP, Vanness K, Barlas A, Manova-Todorova KO, Wen YH, Petrini JH. 2013. The Mre11 complex suppresses oncogenedriven breast tumorigenesis and metastasis. Mol Cell 52: 353-365.

Hartsuiker E, Vaessen E, Carr AM, Kohli J. 2001. Fission yeast Rad50 stimulates sister chromatid recombination and links cohesion with repair. EMBO J 20: 6660-6671.

He H, Wang Y, Guo X, Ramchandani S, Ma J, Shen MF, Garcia DA, Deng Y, Multani AS, You MJ, et al. 2009. Pot1b deletion and telomerase haploinsufficiency in mice initiate an ATRdependent DNA damage response and elicit phenotypes resembling dyskeratosis congenita. Mol Cell Biol 29: 229240.

He J, Shi LZ, Truong LN, Lu CS, Razavian N, Li Y, Negrete A, Shiloach J, Berns MW, Wu X. 2012. Rad50 zinc hook is important for the Mre11 complex to bind chromosomal DNA double-stranded breaks and initiate various DNA damage responses. J Biol Chem 287: 31747-31756.

Hockemeyer D, Palm W, Wang RC, Couto SS, de Lange T. 2008. Engineered telomere degradation models dyskeratosis congenita. Genes Dev 22: 1773-1785.

Hohl M, Kwon Y, Galvan SM, Xue X, Tous C, Aguilera A, Sung P, Petrini JH. 2011. The Rad50 coiled-coil domain is indispensable for Mre11 complex functions. Nat Struct Mol Biol 18: 1124-1131.

Hopfner KP, Craig L, Moncalian G, Zinkel RA, Usui T, Owen BA, Karcher A, Henderson B, Bodmer JL, McMurray CT, et al. 2002. The Rad50 zinc-hook is a structure joining Mre11 complexes in DNA recombination and repair. Nature 418: 562-566.

Kass EM, Helgadottir HR, Chen CC, Barbera M, Wang R, Westermark UK, Ludwig T, Moynahan ME, Jasin M. 2013. Double-strand break repair by homologous recombination in primary mouse somatic cells requires BRCA1 but not the ATM kinase. Proc Natl Acad Sci 110: 5564-5569.

Lammens K, Bemeleit DJ, Mockel C, Clausing E, Schele A, Hartung S, Schiller CB, Lucas M, Angermuller C, Soding J, et al. 2011. The Mre11:Rad50 structure shows an ATPdependent molecular clamp in DNA double-strand break repair. Cell 145: 54-66.

Lim HS, Kim JS, Park YB, Gwon GH, Cho Y. 2011. Crystal structure of the Mre11-Rad50-ATP $\gamma$ S complex: Understanding the interplay between Mre11 and Rad50. Genes Dev 25: 1091-1104.

Liu P, Jenkins NA, Copeland NG. 2003. A highly efficient recombineering-based method for generating conditional knockout mutations. Genome Res 13: 476-484.

Lois C, Hong EJ, Pease S, Brown EJ, Baltimore D. 2002. Germline transmission and tissue-specific expression of transgenes delivered by lentiviral vectors. Science 295: 868-872.

Luo G, Yao MS, Bender CF, Mills M, Bladl AR, Bradley A, Petrini JH. 1999. Disruption of mRad50 causes embryonic stem cell lethality, abnormal embryonic development, and sensitivity to ionizing radiation. Proc Natl Acad Sci 96: 7376-7381.

Marquardt JU, Thorgeirsson SS. 2010. Stem cells in hepatocarcinogenesis: Evidence from genomic data. Semin Liver Dis 30: 26-34.

Martinez P, Thanasoula M, Carlos AR, Gomez-Lopez G, Tejera AM, Schoeftner S, Dominguez O, Pisano DG, Tarsounas M, Blasco MA. 2010. Mammalian Rap1 controls telomere function and gene expression through binding to telomeric and extratelomeric sites. Nat Cell Biol 12: 768-780.

Maryanovich M, Oberkovitz G, Niv H, Vorobiyov L, Zaltsman Y, Brenner O, Lapidot T, Jung S, Gross A. 2012. The ATM- 
BID pathway regulates quiescence and survival of haematopoietic stem cells. Nat Cell Biol 14: 535-541.

Milman N, Higuchi E, Smith GR. 2009. Meiotic DNA doublestrand break repair requires two nucleases, MRN and Ctp1, to produce a single size class of Rec12 (Spo11)-oligonucleotide complexes. Mol Cell Biol 29: 5998-6005.

Morales M, Theunissen JW, Kim CF, Kitagawa R, Kastan MB, Petrini JH. 2005. The Rad50S allele promotes ATM-dependent DNA damage responses and suppresses ATM deficiency: Implications for the Mrell complex as a DNA damage sensor. Genes Dev 19: 3043-3054.

Morales M, Liu Y, Laiakis EC, Morgan WF, Nimer SD, Petrini JH. 2008. DNA damage signaling in hematopoietic cells: A role for Mre11 complex repair of topoisomerase lesions. Cancer Res 68: 2186-2193.

Moreno-Herrero F, de Jager M, Dekker NH, Kanaar R, Wyman C, Dekker C. 2005. Mesoscale conformational changes in the DNA-repair complex Rad50/Mre11/Nbs1 upon binding DNA. Nature 437: 440-443.

Neale MJ, Pan J, Keeney S. 2005. Endonucleolytic processing of covalent protein-linked DNA double-strand breaks. Nature 436: 1053-1057.

Rambo RP, Tainer JA. 2010. Improving small-angle X-ray scattering data for structural analyses of the RNA world. RNA 16: 638-646.

Reina-San-Martin B, Nussenzweig MC, Nussenzweig A, Difilippantonio S. 2005. Genomic instability, endoreduplication, and diminished Ig class-switch recombination in B cells lacking Nbs1. Proc Natl Acad Sci 102: 1590-1595.

Sakai K, Miyazaki J. 1997. A transgenic mouse line that retains Cre recombinase activity in mature oocytes irrespective of the cre transgene transmission. Biochem Biophys Res Commun 237: 318-324.

Shiloh Y, Ziv Y. 2013. The ATM protein kinase: Regulating the cellular response to genotoxic stress, and more. Nat Rev Mol Cell Biol 14: 197-210.

Shiotani B, Nguyen HD, Hakansson P, Marechal A, Tse A, Tahara H, Zou L. 2013. Two distinct modes of ATR activation orchestrated by Rad17 and Nbs1. Cell reports 3: 1651-1662.

Spangrude GI, Heimfeld S, Weissman IL. 1988. Purification and characterization of mouse hematopoietic stem cells. Science 241: 58-62.

Stiff T, Reis C, Alderton GK, Woodbine L, O'Driscoll M, Jeggo PA. 2005. Nbs1 is required for ATR-dependent phosphorylation events. EMBO I 24: 199-208.

Stout GJ, Blasco MA. 2009. Genetic dissection of the mechanisms underlying telomere-associated diseases: Impact of the TRF2 telomeric protein on mouse epidermal stem cells. Dis Model Mech 2: 139-156.

Stracker TH, Petrini JH. 2011. The MRE11 complex: Starting from the ends. Nat Rev Mol Cell Biol 12: 90-103.

Takubo K, Ohmura M, Azuma M, Nagamatsu G, Yamada W, Arai F, Hirao A, Suda T. 2008. Stem cell defects in ATMdeficient undifferentiated spermatogonia through DNA damage-induced cell-cycle arrest. Cell Stem Cell 2: 170-182.

Teoh N, Pyakurel P, Dan YY, Swisshelm K, Hou J, Mitchell C, Fausto N, Gu Y, Farrell G. 2010. Induction of p53 renders ATM-deficient mice refractory to hepatocarcinogenesis. Gastroenterology 138: 1155-1165.e2.

Theunissen JW, Petrini JH. 2006. Methods for studying the cellular response to DNA damage: Influence of the Mre11 complex on chromosome metabolism. Methods Enzymol 409: 251-284.

Theunissen JW, Kaplan MI, Hunt PA, Williams BR, Ferguson DO, Alt FW, Petrini JH. 2003. Checkpoint failure and chromosomal instability without lymphomagenesis in Mre11(ATLD1/ATLD1) mice. Mol Cell 12: 1511-1523.
Usui T, Petrini JH, Morales M. 2006. Rad50S alleles of the Mre11 complex: Questions answered and questions raised. Exp Cell Res 312: 2694-2699.

van Noort J, van Der Heijden T, de Jager M, Wyman C, Kanaar R, Dekker C. 2003. The coiled-coil of the human Rad50 DNA repair protein contains specific segments of increased flexibility. Proc Natl Acad Sci 100: 7581-7586.

Ventura A, Kirsch DG, McLaughlin ME, Tuveson DA, Grimm J, Lintault L, Newman J, Reczek EE, Weissleder R, Jacks T. 2007. Restoration of p53 function leads to tumour regression in vivo. Nature 445: 661-665.

Williams RS, Moncalian G, Williams JS, Yamada Y, Limbo O, Shin DS, Groocock LM, Cahill D, Hitomi C, Guenther G, et al. 2008. Mre11 dimers coordinate DNA end bridging and nuclease processing in double-strand-break repair. Cell 135: 97-109.

Williams RS, Dodson GE, Limbo O, Yamada Y, Williams JS, Guenther G, Classen S, Glover JN, Iwasaki H, Russell P, et al. 2009. Nbs1 flexibly tethers Ctp1 and Mre11-Rad50 to coordinate DNA double-strand break processing and repair. Cell 139: 87-99.

Wiltzius JJ, Hohl M, Fleming JC, Petrini JH. 2005. The Rad50 hook domain is a critical determinant of Mrel1 complex functions. Nat Struct Mol Biol 12: 403-407.

Yang YG, Saidi A, Frappart PO, Min W, Barrucand C, DumonJones V, Michelon J, Herceg Z, Wang ZQ. 2006. Conditional deletion of Nbs1 in murine cells reveals its role in branching repair pathways of DNA double-strand breaks. EMBO I 25: 5527-5538.

Zhang S, Yajima H, Huynh $\mathrm{H}$, Zheng J, Callen E, Chen HT, Wong N, Bunting S, Lin YF, Li M, et al. 2011. Congenital bone marrow failure in DNA-PKcs mutant mice associated with deficiencies in DNA repair. J Cell Biol 193: 295-305. 


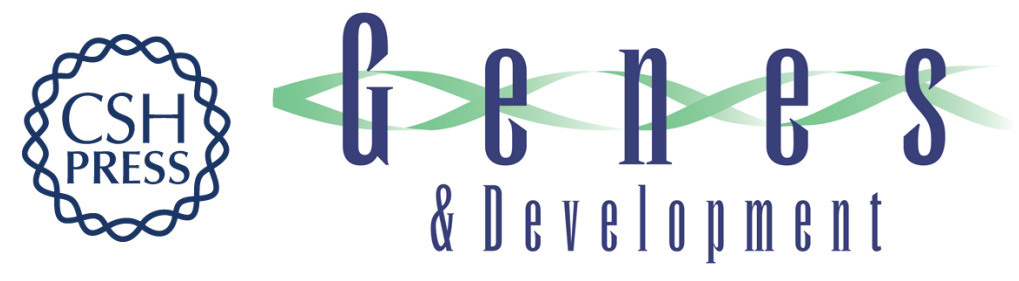

\section{The Rad50 hook domain regulates DNA damage signaling and tumorigenesis}

Ramon Roset, Akiko Inagaki, Marcel Hohl, et al.

Genes Dev. 2014, 28: originally published online February 14, 2014

Access the most recent version at doi:10.1101/gad.236745.113

\section{Supplemental http://genesdev.cshlp.org/content/suppl/2014/02/07/gad.236745.113.DC1 Material}

References This article cites 59 articles, 27 of which can be accessed free at: http://genesdev.cshlp.org/content/28/5/451.full.html\#ref-list-1

Creative This article is distributed exclusively by Cold Spring Harbor Laboratory Press for the first Commons six months after the full-issue publication date (see

License http://genesdev.cshlp.org/site/misc/terms.xhtml). After six months, it is available under a Creative Commons License (Attribution-NonCommercial 3.0 Unported), as described at http://creativecommons.org/licenses/by-nc/3.0/.

Email Alerting Receive free email alerts when new articles cite this article - sign up in the box at the top Service right corner of the article or click here.

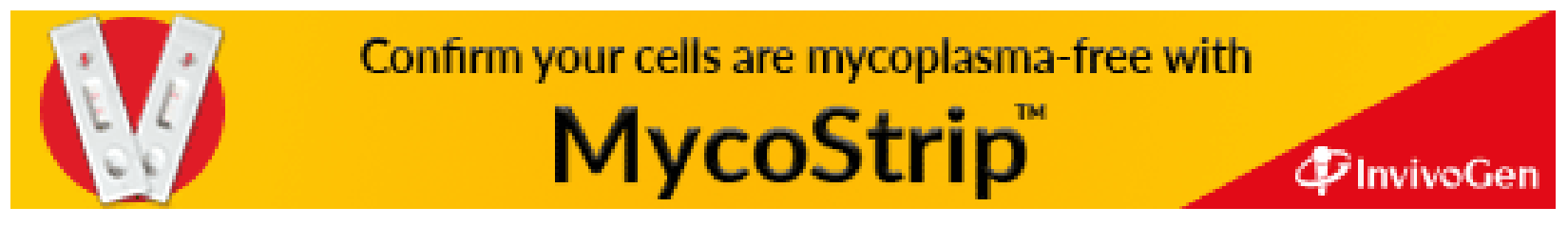

